\title{
Academic libraries and research in flux
}

\section{Global conversations in times of COVID-19}

I n March 2020, Alameda County, where the University of California (UC)-Berkeley is located, issued a shelter in place order as a response to the COVID-19 pandemic. The UC-Berkeley Library was one of the first libraries in the United States to deal effectively with the new normal that was mandated by local, state, and federal public health officials, shifting to the virtual provision of its services such as instruction, research consultation, and accelerated e-resource acquisition. Library administration encouraged staff to think creatively, to not only provide our services to faculty, users, and students, but also to bridge the physical gap through virtual media to foster collaboration among the community of international librarians.

As the librarian responsible for collecting, curating, and providing instruction and reference for two large geographic areas (Eastern Europe and Eurasia, and the Caribbean and Latin America) and given my international studies background, I started to think about what I could do to create a virtual place for academic librarians from different parts of the world to speak about their efforts in mitigating the effects of COVID-19 in their specific contexts. Even though these librarians are on different continents, we are all bound by certain commonalities. I thought that webinars could serve as a milieu where librarians can freely express their concerns, share ideas, their successes, and their adaptations to the new working realities in the epoch of isolation and insecurity. This led to the launching of the series, "Collecting Conversations: Academic Libraries and Research in Flux."
While the webinars were open to an international audience and covered experiences in and outside of the United States, a priority of this webinar series was to provide a platform for US-based librarians to hear firsthand how librarians from other parts of the world were innovative in their own right, when it came to providing similar services to their patrons under perhaps more severe constraints. The focus of this article is to reflect on what was learned from the three of the six webinars (\#1, 2 and 4) focusing on experiences outside of the United States.

\section{Boundless conversations}

I had planned the series with academic librarians in mind. However, I realized that the program should also be geared towards all information professionals. The webinars were intended to serve not only as a safe space, but also as a venue for the exchange of individual librarian experiences about how they and their organizations have dealt with the COVID-19 externalities. At the time of writing this article, I had presented the initial five webinars:

Liladhar R. Pendse is librarian for East European, Central Asian Studies and Librarian for the Caribbean and Latin American Studies at the University of California-Berkeley, email: Ipendse@library.berkeley.edu

Contact column editors Clara M. Chu, Mortenson Distinguished Professor, University of Illinois Urbana Champaign (cmchu@illinois.edu), and Jaya Raju, professor and head of department, University of Cape Town (jaya. raju@uct.ac.za), with questions about the International Insights column or to suggest future article topics.

(0) 2021 Liladhar R. Pendse 
1. COVID-19: European Librarians Speak! (August 6, 2020)

2. COVID-19: The Caribbean and Latin American Information Professionals and Academic Library Directors Speak! | ¡Informan los profesionales de la información y las directoras de bibliotecas académicas del Caribe y América Latina! | COVID-19: Profissionais e Diretores de Bibliotecas Acadêmicas do Caribe e América Latina com a palavra! (September 17, 2020)

3. COVID-19: North American, East European, and Eurasian Studies Librarians Talk Pandemic Response! (September 24, 2020)

4. COVID-19:

Library Leaders and Administrators Speak! (October 30, 2020)

5. COVID-19: Israeli and Jewish Studies Librarians Speak! (November 19, 2020)

The last webinar is in the planning phases and includes Special Collections curators from the American

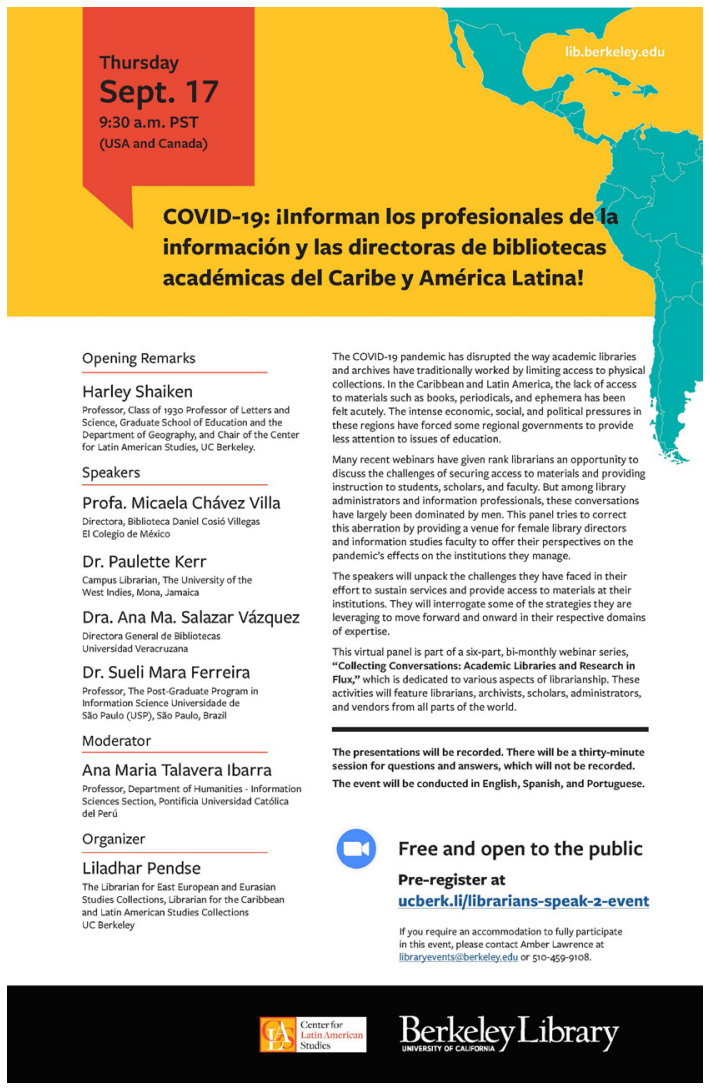

Image 1.TheSpanish-languageversion of the firstwebinarflyer.
South. It closes out

the webinar series, covering both domestic and international issues, that academic librarians, globally, have been facing since January 2020, the start of the COVID-19 pandemic.

The first webinar took place on August 6, 2020, with participation from Mel Bach, Slavonic specialist and also head of collections and academic liaison at Cambridge University Library (UK); Olaf Hamann, head of the Eastern-European Branch of the Berlin State
Library (Germany); Katya Rogatchevskaia, lead curator of East European Collections at the British Library (UK) and chair of the Council for Slavonic and East European Library and Information Services; and Gudrun Wirtz, head of the Department of Eastern Europe at the Bavarian State Library (Germany).

All speakers discussed their individual library's strategies on closing libraries or keeping them open throughout the COVID-19 safety measures. While British colleagues explained that their library's physical spaces were closed during the United Kingdom's national lockdown, the German colleagues reported a slightly different picture. For example, the Bavarian State Library's physical spaces have remained open since March 2020 and social distancing was enforced per health directives, while the Berlin State Library's employees transitioned into the home office scenario. In this webinar, our British Library (BL) colleague mentioned that their users could only access the proprietary-licensed databases on BL site. Moreover, while BL's physical space remained inaccessible during the closure, BL's digital collections remained accessible. ${ }^{1}$ Its reading rooms were reopened on July $24 .^{2}$

The next webinar, "COVID-19: The Caribbean and Latin American Information Professionals and Academic Library Directors Speak!" had two specific objectives: 1) 
to involve as many library managers and faculty members in library and information science from Latin America and the Caribbean as possible in the one-hour webinar, and 2) to provide a forum for women administrators and faculty to speak up about their concerns and hurdles they might have faced due to COVID-19 and their gender. At the UC-Berkeley Library, we created flyers in English, Spanish, and Portuguese. Image 1 shows the Spanish version of the flyer. The creation of multilingual flyers was to be inclusive, one of UCBerkeley's values, in order to reach many in the nonEnglish-speaking library community in Latin America. Knowing that attendees were registering from across Latin America and the Caribbean, the selected moderator knew the subject matter and could facilitate the multilingual session, as the presenters were given the choice to speak in their native tongue, and chose to speak in

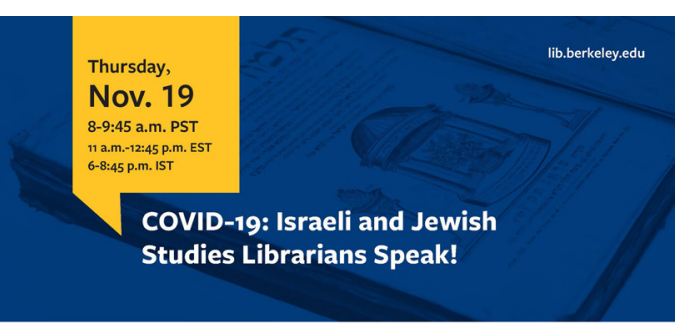

were being provided remotely throughout the closure. Sueli Mara Ferreira focused on copyright concerns, as they are likely to be exacerbated during the COVID-19 library closures in Brazil. This second webinar, once again made it clear that most academic institutions opted for user security while continuing to provide library services remotely.

Lastly, on November 19, Jewish Studies librarians and library directors from Israel spoke about how they are dealing with the COVID-19 situation in their academic and professional lives. I was initially uncertain about how to organize an event that included librarians from Israel, as I did not know any of these university librarians/library directors personally. However, when I wrote to several university librarians in Israel explaining the purImage 2. Webinar flyer for COVID-19 Israeli and Jewish with Ruth Haber, Studies Librarians Speak! that language.

In this webinar, Harley Shaiken opened the session by highlighting some of the key findings from the latest World Bank report. ${ }^{3}$ The two panelists from Mexico focused on how their libraries were in the process of sanitizing the library's physical spaces during the closure. Paulette Kerr from Jamaica reaffirmed the library and university's commitment to patron safety in light of COVID-19 and highlighted their $24 / 7$ user services that pose of the webinar series, I received enthusiastic and positive responses. I also consulted Register at ucberk.li/librarians-speak-5-even If you require an accommocation to fully particip
in this event, please contact Amber Lawrence at

\section{BerkeleyLibrary}

librarian for Judaica collections at UCBerkeley, and she invited the presidentelect of the Association of Jewish Libraries, Michelle Chesner from Columbia University Library, who then suggested Yoel Finkelman of Israel's National Library and Ilana Tahan of the British Library. Image 2 shows the flyer that UC-Berkeley Library's communications prepared for this event.

Yoel Finkelman, curator of the Haim and Hanna Solomon Judaica Collection at the 
National Library of Israel, focused on three important aspects of the work of the National Library of Israel during the lockdown. He presented his work on collecting COVID-19related ephemera items from all over the world produced by Jewish community organizations. ${ }^{4}$ He described the measures that the administration of the National Library of Israel undertook that led to preservation of library jobs in light of budgetary downturns, and emphasized that the construction of the new building of the National Library of Israel continued despite the COVID-19-mandated externalities.

The directors of the three major academic libraries in Israel-Olga Goldin (University Library System, Bar-Ilan University), Naomi Gredinger (Younes \& Soraya Nazarian Library, Haifa University), and Naama Scheftlowitz (Sourasky Central Library, Tel-Aviv University)—described their COVID-19 responses to provide effective and accessible services. For example, the Bar-Ilan University Library is scanning books for their users, shifting from the analog delivery of interlibrary loan materials to e-delivery, and has been creating a series of videos that deal with COVID-19-related issues. ${ }^{5}$ They further discussed their efforts in preserving the safety and jobs of their personnel.

Gredinger highlighted a series of COVID-19-related issues that the Haifa University Library is hosting. The title of the series is "שיחות על ספריות בימי קורונה," and can be translated as "Conversations about the Corona era libraries." These events are in Hebrew and open to all.

Ilana Tahan, lead curator of Hebrew and Christian Orient Studies, highlighted BL's efforts to mitigate the effects of COVID-19 and her use of digital collections in providing reference and user services. She showed the audiences several images of digitized Hebrew manuscripts of the Polontsky Foundation that are hosted at the British Library.

\section{Reflections}

These webinars brought together librarians from different countries and continents to speak about their individual experiences. They were a collaborative effort, which included colleagues from the library's communication team who created our posters, several different curators at UC-Berkeley who came up with scenarios and circumstances to make these webinars open and accessible to all of the attendees, and others worldwide who provided recommendations and assisted in promoting the program internationally. The challenge was to make these relevant and interesting to the global library audience, and enable participation across different timezones.

For example, in the case of the webinar with the librarians from Israel, they participated outside of their work schedule. The spirit of contributing to and volunteering in this webinar series by our participants from around the globe serves as the seed of potential fruitful international collaboration among the librarians.

The library has displaced itself outside of its walls, is the conclusion I've reached from listening to my colleagues. The physical library, however, remains essential to providing access to certain materials and services. In the initial phases of the COVID-19-mandated closure, librarians focused on e-services, digital products, and online platforms to meet user needs. While the same trend has continued and, in some cases, libraries have had to close their doors again as the COVID-19 infections resurged, librarians have invented unique ways to overcome the social isolation that many are experiencing in light of COVID-19-mandated stay-at-home regulations.

For example, in Israel, the library directors have weekly and monthly meetings to communicate their experiences about what worked for them and what did not. Regularly scheduled meetings are also being held in academic libraries across the globe that are a combination of updates on recent developments and policies, and conversations to connect and support each other by discussing experiences, opportunities, challenges, and solutions. Librarians and staff all over the world are also organizing webinars that 
highlight and share their experiences during the "corona."

While some experiences and solutions were different depending on local financial and personnel resources, infrastructure, and institutional COVID-19 mandates, allowing institutions to do more or less, the prioritizing and commitment to personnel and their user community were unwavering. Of the many strategies reported, three priorities were unmistakable when it came to dealing with corona: the safety of staff and users, the security of library materials, and the security of jobs while keeping employee morale up. I have learned that despite all of the differences due to languages, borders, and nationstate mandated regulations, what unites us, as library and information practitioners, is our enthusiasm for helping our users while supporting ourselves. We have much more in common than linguistic, political, and socio-cultural differences. As the pandemic continues to thrust itself upon us, we have learned to keep the library going to serve our community. Instead of building walls, we have built bridges, leveraging our ingenuity, technology, and collaborative spirit.

\section{Notes}

1. British Library, "Access to the British Library during Temporary Closure," British Library News, March 19, 2020, https:// www.bl.uk/news/2020/march/access-to -the-british-library-during-temporary-closure (accessed November 16, 2020).

2. British Library, "We're Back," British Library News, July 24, 2020, https://www. bl.uk/news/2020/july/we-cant-wait-to-see -you-again (accessed November 16, 2020).

3. World Bank, "Reversals of Fortune," Poverty and Shared Prosperity 2020, https:// www.worldbank.org/en/publication/poverty -and-shared-prosperity (accessed November 16, 2020).

4. Marcy Oster, "National Library Launches Project to Document Coronavirus Impact on Jewish Life," The Times of Israel, March 30, 2020, https://www.timesofisrael.com /national-library-launches-project-to -document-coronavirus-impact-on-jewish -life/ (accessed November 20, 2020).

5. "Campaña COVID-19 Bar-Ilan University," 2020, https://www.youtube.com /watch?v=3FVZYh2SgAc (accessed November 20, 2020).

\section{("Developing an assessment plan," continued from page 34)}

to hold yearly assessment retreats to analyze data and discuss changes to the curriculum for the following year.

Document every decision. Early on we did not take extensive notes during meetings, which we regretted. With all the changes you will make to your SLOs, assessments, and curriculum throughout this process, it is important to document each decision you make. Assign a notetaker for each discussion, and keep notes in a central location for easy access.

Determine a project manager, but share the work. There are a lot of moving parts to this process, and a project manager is key. Our project manager was the committee chair. This person determined the timeline, set meetings, kept track of each phase, and assigned tasks. While it is important to have a project manager, the work must be shared. For one, it is too much work for one person. More importantly, sharing the work builds buy-in and ownership of the process for all instruction librarians.

Developing an assessment plan for shared information literacy learning outcomes is a time-intensive process, but it is possible with teamwork, organization, and a willingness to revisit past decisions.

\section{Notes}

1. Andrea Falcone and Lyda McCartin, "Be Critical, But Be Flexible: Using the Framework to Facilitate Student Learning Outcome Development," CERL News 79, no. 1 (2018): 16-19.

2. Office of Institutional Research, Plan-

(continues on page 44) 